\title{
Ecophysiology of Andropogon grass subjected to different cutting frequencies and intensities
}

\author{
Juliana R. L. Lima ${ }^{1}$, Rosane C. Rodrigues ${ }^{1}$, Giovanne O. C. Sousa ${ }^{1}$, Clésio dos S. Costa ${ }^{2}$, \\ Henrique N. Parente ${ }^{1} \&$ Francisco N. de S. Santos ${ }^{3}$
}

\begin{abstract}
${ }^{1}$ Universidade Federal do Maranhão/Centro de Ciências Agrárias e Ambientais. Chapadinha, MA, Brasil. E-mail: juliana934lacerda@hotmail.com - ORCID: 0000-0003-0069-7410; rosanerodrigu@gmail.com - ORCID: 0000-0001-8561-9678; giovanneolivei75@gmail.com - ORCID: 0000-0001-9713-1581; hnparentes@hotmail.com - ORCID: 0000-0001-5706-2323

${ }^{2}$ Universidade Federal do Ceará/Departamento de Zootecnia. Fortaleza, CE, Brasil. E-mail: clesiosantzooo@gmail.com - ORCID: 0000-0003-0451-7157

${ }^{3}$ Universidade Federal da Paraíba/Departamento de Zootecnia. Areia, PB, Brasil. E-mail: nayssonzootecnista@gmail.com (Corresponding author) - ORCID: 0000-0001-6968-1738
\end{abstract}

\begin{abstract}
The objective of this study was to evaluate the morphogenic and structural characteristics, and demographic patterns of Andropogon gayanus subjected to different cutting frequencies and intensities. A completely randomized design was adopted in a $3 \times 2$ factorial arrangement, corresponding to three cutting heights $(50,70$, and $90 \mathrm{~cm})$, and two cutting intensities (50 and 70\%) with four repetitions, totaling 24 plots of $7.50 \times 6.25 \mathrm{~m}$. For morphogenesis, there was no interaction effect $(\mathrm{P} \leq 0.05)$ of treatments on stem elongation rate, leaf appearance rate, and phyllochron rate. The highest rate of leaf elongation was observed at a height of $90 \mathrm{~cm}$ and cut intensity of $50 \%$, with 1.69 and $0.84 \mathrm{~cm} \mathrm{tiller}^{-1} \mathrm{~d}^{-1}$ of leaf elongation at heights of 50 and $70 \mathrm{~cm}$, respectively. For forage production, there was no interaction ( $\mathrm{p}>0.05)$ between cutting intensity and cutting height. When the pasture was managed to a cutting height of $90 \mathrm{~cm}$, there was a greater increase in dry leaf mass, stalk dry mass, dead forage dry mass, and total dry forage mass, which was $50.89 \%$ and $53.29 \%$ higher than pasture heights of 50 and $70 \mathrm{~cm}$, respectively. There was no interaction between factors on demographic characteristics ( $p>0.05$ ). A cutting height of $70 \mathrm{~cm}$ with a cutting intensity of $50 \%$ is recommended when handling this grass.
\end{abstract}

Key words: Andropogon gayanus, cutting height, morphogenic characteristics, forage production

\section{Ecofisiologia do capim Andropogon submetido a diferentes frequências e intensidades de corte}

\begin{abstract}
RESUMO: Objetivou-se avaliar as características morfogênicas e estruturais e os padrões demográficos do capim-andropógon submetido a diferentes frequências e intensidades de corte. Adotou-se o delineamento inteiramente casualizado em arranjo fatorial $3 \times 2$, correspondente a três alturas de corte $(50,70$ e $90 \mathrm{~cm}) \mathrm{e}$ duas intensidades de corte (50 e 70\%) com quatro repetições, totalizando 24 parcelas de 7,50 x 6,25 m. Para as características morfogênicas houve efeito $(\mathrm{p} \leq 0,05)$ da interação na taxa de alongamento do colmo, taxa de aparecimento de folhas e taxa de filocrono. A maior taxa de alongamento foliar foi observada na altura de $90 \mathrm{~cm}$ e intensidade de corte de 50\%, apresentando 1,69 e $0,84 \mathrm{~cm}_{\text {perfilho }} \mathrm{d}^{-1}$ de alongamento foliar nas alturas de 50 e $70 \mathrm{~cm}$, respectivamente. Para produção de forragem não foi verificado efeito da interação $(\mathrm{p}>0,05)$ entre as intensidades de corte e altura de corte. Quando o pasto foi manejado com altura de corte de $90 \mathrm{~cm}$, observou-se maior incremento de massa seca foliar, massa seca de colmo, massa seca de forragem morta e massa seca de forragem total, a qual foi superior em 50,89 e 53,29\% em relação às alturas de 50 e $70 \mathrm{~cm}$, respectivamente. Para as características demográficas do capim andropógon não se observou efeito da interação entre os fatores $(\mathrm{p}>0,05)$. Recomenda-se a altura de corte de $70 \mathrm{~cm}$ com intensidade de corte de $50 \%$ no manejo desta gramínea.
\end{abstract}

Palavras-chave: Andropogon gayanus, altura de corte, características morfogênicas, produção de forragem 


\section{INTRODUCTION}

In the feeding of ruminants, plants of the Poaceae family are the most economical and practical part of the productive system, as long as the pasture is managed efficiently. It is a priority to optimize the use of cultivated pastures by adopting strategic management practices, while increasing the availability of nutrients for the animals via grazing optimization. Ecophysiology explains the morphophysiological responses of plants in environments in which they grow as a result of the management practices adopted. Understanding these changes facilitates the establishment of management practices consistent with the productive capacity of forage plants in a particular context (Pimentel et al., 2016). The frequency of defoliation or cutting changes the structure of the pasture, and the flow of biomass available to the animal via grazing, which can compromise the production and the nutritional value of grasses. Thus, the intensity of defoliation refers to how much the animal has removed from the plant in relation to what was made available for it to graze (Lemaire et al., 2011).

Andropogon spp. belong to the Poaceae family, and are resilient to drought conditions and low soil fertility (Veras et al., 2010). A cespitous growth form, and a high rate of elongation of the stem in the vegetative phase interfere with the structure of the canopy, and the process of competition for light (Silva \& Sbrissia, 2001), which affects the accumulation of forage.

Therefore, the objective of this study was to evaluate the morphogenic and structural characteristics, and the demographic patterns of Andropogon gayanus grass subjected to different cutting frequencies and intensities.

\section{Material ANd Methods}

The experiment was conducted in the forage section of the Center for Agricultural and Environmental Sciences at UFMA University, at Chapadinha ( $3^{\circ} 44^{\prime} 33^{\prime \prime} \mathrm{S}, 43^{\circ} 21^{\prime} 21^{\prime \prime} \mathrm{W}$ ), at an altitude of $105 \mathrm{~m}$, under rainfed conditions. The experimental area of $1125 \mathrm{~m}^{2}$ was divided into 24 experimental plots $(7.50 \times$ $6.25 \mathrm{~m}$ ) with Andropogon gayanus Kunth 'Planaltina'.

The completely randomized, $3 \times 2$ factorial design corresponded to three cutting heights (moment of cutting when the plant reached 50, 70, and $90 \mathrm{~cm}$ ), and two cutting intensities (50 and 70\%), totaling six treatments with four repetitions.

During the experimental period, the average temperature did not exceed $30{ }^{\circ} \mathrm{C}$, with the highest monthly average $\left(27.4^{\circ} \mathrm{C}\right)$ observed in June. The months of February, March, and April had the highest rainfall of 356.1, 411.1, and $331.7 \mathrm{~mm}$, respectively (Figure 1).

The soil in the experimental area was classified as Oxisol, with the following chemical characteristics in the surface layer (0 to $0.2 \mathrm{~m}$ ): $\mathrm{pH}$ in $\mathrm{CaCl}_{2}=4.1 ; \mathrm{P}$ (res) $=8.0 \mathrm{mg} \mathrm{dm}^{-3} ; \mathrm{K}=$ $0.14 \mathrm{cmol}_{\mathrm{c}} \mathrm{dm}^{-3} ; \mathrm{Ca}$ and $\mathrm{Mg}=0.3$ and $0.1 \mathrm{cmol}_{\mathrm{c}} \mathrm{dm}^{-3} ; \mathrm{Al}$ and $\mathrm{H}=0.6$ and $2.8 \mathrm{cmol}_{\mathrm{c}} \mathrm{dm}^{-3}$; and organic matter $=18 \mathrm{~g} \mathrm{~kg}^{-1}$. This was performed using the liming method elevation of base saturation, increasing it to $50 \%$. Fertilization was carried out with nitrogen, phosphorus, and potassium, at the following doses: $120 \mathrm{~kg} \mathrm{ha}^{-1} \mathrm{~N}, 30 \mathrm{~kg} \mathrm{ha}^{-1} \mathrm{P}_{2} \mathrm{O}_{5}$, and $100 \mathrm{~kg} \mathrm{ha}^{-1}$ of $\mathrm{K}_{2} \mathrm{O}$ in the form of urea, superphosphate, and potassium chloride, respectively. Phosphorus was applied in a single dose, while potassium and nitrogen were split three times $\left(33.3 \mathrm{~kg}\right.$ of $\mathrm{K}_{2} \mathrm{O}$, and $40 \mathrm{~kg}$ of $\mathrm{N}$ ), by hauling.

At the beginning of the experimental period, all 24 experimental plots were standardized at $15 \mathrm{~cm}$ high by cutting with a brush cutter in February 2017, and from then on, the entire pasture was managed at the three cutting heights (50,70, and $90 \mathrm{~cm}$ ), and two cutting intensities (50 and 70\%).

Morphogenic evaluations were performed at each cut using a millimeter ruler. In each plot, four clumps of grass were marked, in which each tiller was marked with threads of different colors. The following morphogenic variables were evaluated: leaf appearance rate (LAR; number of leaves appearing by tiller divided by the number of days in the evaluation period; tiller ${ }^{-1} \mathrm{~d}^{-1}$ ), leaf elongation rate (LER; sum of leaf blade elongation per planting divided by the number of days in the evaluation period; $\mathrm{cm}$ tiller ${ }^{-1} \mathrm{~d}^{-1}$ ), stem elongation rate (SER: the sum of stem elongation per plantation divided by number of days of the evaluation period; $c$ rudder $\left.^{-1} \mathrm{~d}^{-1}\right)$, and leaf senescence rate (LSR; average and negative variation in leaf blade length resulting from the decrease in the green portion of the leaf blade; $\mathrm{cm}$ profile $\left.\mathrm{e}^{-1} \mathrm{~d}^{-1}\right)$. The following structural

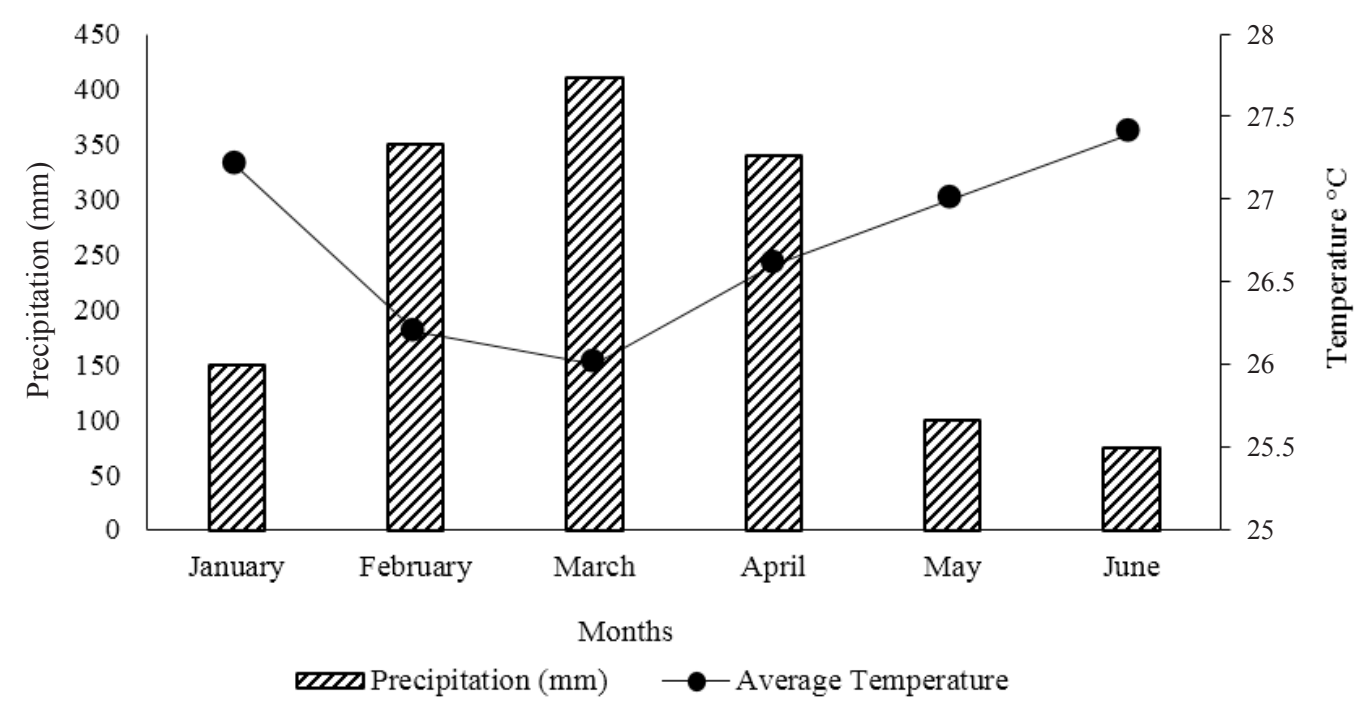

Figure 1. Precipitation and average temperature from January to June 2017 
characteristics were measured: phyllochron (PHY; inverse of the rate of appearance of the leaves (days leaf ${ }^{-1}$ profile $^{-1}$ ); number of leaves with no-tillage (NL; average number of leaves in elongation and expanded by no-tillage, disregarding the senescent leaves of each tiller), and final leaf length (FLL; average length of all leaves present in the tiller; $\mathrm{cm}$ ).

The leaf measurements were taken from the live plant measured from the ligule to the leaf end, while the stem was measured from the base to the exposed ligule of the emerging leaf.

For the evaluation of the demographic characteristics of A. gayanus, two clumps were chosen per plot, in which two PVC rings $25 \mathrm{~cm}$ in diameter and $2 \mathrm{~cm}$ in height were fixed to the soil per plot, in areas representative of the average of the pasture. According to the visual assessment of the height and forage mass in each tiller within the PVC pipe, tillers were marked with threads of a similar color (Carvalho et al., 2000).

The evaluations were carried out at the end of each grass production cycle, in which the live tillers (out of the base generation $(\mathrm{Bg})$, and the dead), were counted and calculated by difference.

The new generations of tillers that appeared between the sampling periods were marked with a different color thread. Each new, successive generation was numbered (G1, G2, etc.).

The profile of each new generation was re-evaluated. From this information, it was possible to establish tiller appearance rates (TAR), tiller mortality rate (TMort), and tiller survival rate (TSR). Tiller population density was calculated as the ratio of the number of live tillers from the beginning to the end of the cycle. Tiller and TSR were used to calculate the stability index (SIn) of the tiller population. These variables were quantified using the following formulae:

$$
\mathrm{TAR}=\frac{\text { number of new tillers marked }}{\text { number of live in the previous generation }} 100
$$

$$
\mathrm{TSR}=\frac{\text { number of surviving tillers }}{\text { number of live tillers in the previous generation }} 100
$$

$$
\text { TMort }=100-\mathrm{TSR}
$$

Forage production was measured with the aid of a PVC pipe frame, with dimensions of $0.50 \times 0.50 \mathrm{~m}$. The productive characteristics were: dry mass of total forage (DMTF; sum of total dry mass of green consisting of stalk plus leaves and accumulation of dead material), dry mass of leaves
(DFM), stems (DSM), mass dry fodder (MDF), blade to stem ratio (LB/SR), and tiller population density (TPD). These parameters were estimated by cutting two samples from each plot by throwing the PVC frame at random and using this as a perimeter. The samples were cut to the established height of $10 \mathrm{~cm}$, after which the material was packed in plastic bags, properly identified and transported to the laboratory. The material was fractionated at the laboratory into leaf blade, stalk, and dead material, and placed in marked paper bags, weighed, and dried in a forced draught oven at $55^{\circ} \mathrm{C}$ for $72 \mathrm{~h}$ to obtain the dry weight and subsequent production estimate of dry matter. The blade to stem ratio (LB/SR) was determined using the following equation:

$$
\frac{\mathrm{LS}}{\mathrm{S} \text { ratio }}=\frac{\mathrm{MDF}}{\mathrm{DSM}}
$$

The data were subjected to tests to verify that they met the basic assumptions to be subjected to analysis of variance. According to the criteria, the data were submitted to analysis of variance and the Tukey test with the aid of the PROC GLM procedure of the statistical software SAS 9.0 (2002).

\section{RESUlts AND Discussion}

There was an effect $(\mathrm{p} \leq 0.05)$ of the interaction on the stem elongation rate (SER) (Table 1). Grass managed at $50 \mathrm{~cm}$ height and $50 \%$ intensity showed a lower SER $\left(0.46 \mathrm{~cm} \mathrm{~d}^{-1}\right)$. Grass under these conditions is of a better quality, because the elongation of the stalk decreases the percentage of use by the animal, since the stalk has higher concentrations of fibrous components.

A greater proportion of stalks, in places where pasture is managed to greater heights (Table 1), may be the result of the high competition for light between the tillers in these places. Consequently, the upper part of the canopy intercepts more photosynthetically active radiation (Santos et al., 2017).

For the $70 \%$ cut intensity, no difference was found in the stem elongation for the three cutting heights $(50,70$, and 90 $\mathrm{cm}$ ), but at a height of $90 \mathrm{~cm}$, a lower SER was observed at the $70 \%$ cut intensity $\left(0.51 \mathrm{~cm}^{\text {tiller-1 }} \mathrm{d}^{-1}\right)$, when compared to the $50 \%$ intensity $\left(1.28 \mathrm{~cm} \mathrm{tiller}^{-1} \mathrm{~d}^{-1}\right)$. This may be associated with greater competition for light among the tillers (Sbrissia et al., 2010), which causes greater stem elongation and, consequently, a greater increase in forage mass. A cutting intensity of $50 \%$ at a height of $90 \mathrm{~cm}$ presented a higher SER, with a concomitantly greater dry stem mass (DSM).

Table 1. Morphogenic and structural characteristics of A. gayanus subjected to three cutting heights and two cutting intensities

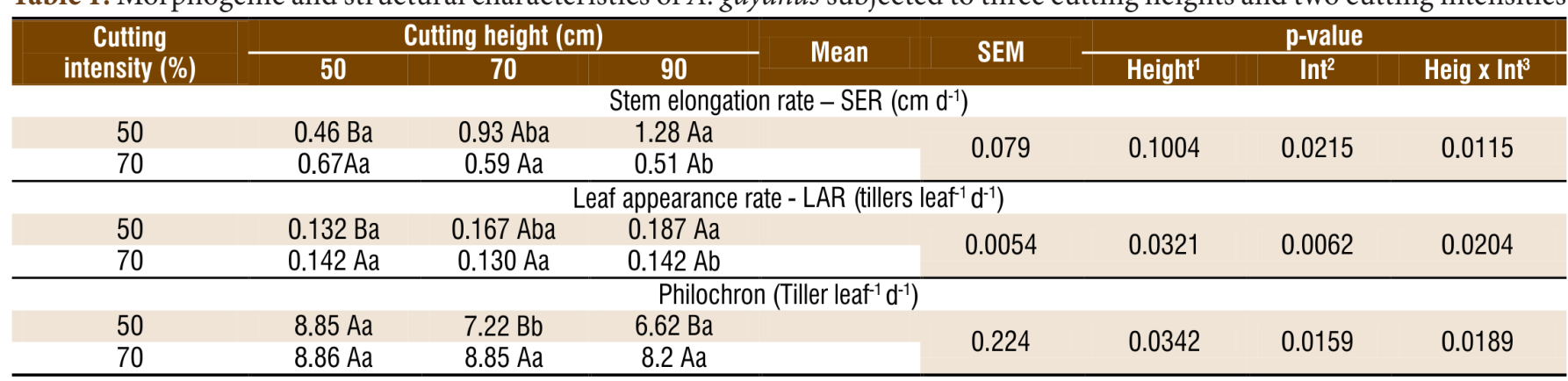

Means followed by uppercase letters in the lines and lowercase letters in the columns do not differ by Tukey's test at $\mathrm{p} \leq 0.05 ; 1$ - Cutting height effect; 2 - Effect of cutting intensity;

3 - Effect of interaction;. SEM - Standard error mean 
The highest LAR at $50 \%$ intensity was observed at 70 and $90 \mathrm{~cm}$, with 0.167 and 0.187 tillers $^{-1} \cdot \mathrm{d}^{-1}$, respectively. In a study by Araújo et al. (2015), with Andropogon spp. under different forage offerings to sheep $(11,15$, and $19 \%$ of sheep live weight), corresponding to $85.30,75.82$, and $132.65 \mathrm{~cm}$ of canopy height, respectively, obtained different results to the current study. When the pasture was kept at lower heights at offerings of 11 and $15 \%$ live weight, LAR values were 0.14 and 0.13 tillers $^{-1} . \mathrm{d}^{-1}$, respectively, with LAR values lower than those found at heights of 70 and $90 \mathrm{~cm}$. There is a higher SER at this height, with a greater number of leaves, with small and thin leaves.

At a cutting intensity of 50\%, the largest phyllochron was observed at a height of $50 \mathrm{~cm}\left(8.85\right.$ tillers $\left.^{-1} . \mathrm{d}^{-1}\right)$, which was $18.41 \%$ and $25.19 \%$ higher than at 70 and $90 \mathrm{~cm}$ in height, respectively (Table 1 ). This explains the greater LAR observed 70 and $90 \mathrm{~cm}$, since the interval for the appearance of two consecutive leaves was shorter than that observed when cutting at a height of $50 \mathrm{~cm}$. At $70 \%$ intensity, the phyllochron did not vary $(p>0.05)$ between cutting heights.

For LER, no interaction was observed between cut height and cut intensity, with the highest LER seen at a height of $90 \mathrm{~cm}$ and cut intensity of $50 \%$. At a height of $90 \mathrm{~cm}$, leaf elongation was 1.69 and $0.84 \mathrm{~cm} \mathrm{leaf}^{-1} \mathrm{~d}^{-1}$ greater than at 50 and $70 \mathrm{~cm}$, respectively (Table 2 ).

Leaf elongation at a cut intensity of $50 \%$ was $0.99 \mathrm{~cm} \mathrm{leaf}^{-1} \mathrm{~d}^{-1}$ longer than at $70 \%$. This can be explained by the effect of the remaining photosynthetically active area, since at an intensity of $70 \%$, there was greater removal of plant tissue. According to Lemaire et al. (2011), the grazing intensity influences the remaining photosynthetically active leaf area, and the remobilization of organic reserves.

There is a positive correlation between LER and the yield of remaining leaves in the tiller after cutting (Martuscello et al., 2015). This explains the higher LER at a height of $90 \mathrm{~cm}$ with a cutting intensity of $50 \%$, since the residue $(45 \mathrm{~cm})$ in the pasture was greater than the residue $(27 \mathrm{~cm})$ at $70 \%$ intensity. The time for the remaining leaves to perform photosynthesis, enabled a faster recovery of the canopy. At a height of 90 $\mathrm{cm}$, greater accumulation of senescent material (LSR) was observed, with no difference between the cutting intensities (50 and $70 \%$ ). With the longer cutting interval to reach $90 \mathrm{~cm}$, the tallest pasture had a larger number of leaves (1.87 leaves), and the upper leaves ended up shading the lower leaves, implying the passage of better quality light.
The lowest number of leaves was found in the pasture managed at a height of $50 \mathrm{~cm}$, with 1.49 tiller leaves $^{-1}$. It was found that the tallest grass had a direct influence on the number of leaves of A. gayanus tillers. This response is due to the higher senescence rate of the leaves at the taller heights (70 and $90 \mathrm{~cm}$ ), as for each leaf that dies, another one starts. According to Lemaire and Chapman (1996), the number of live leaves per tiller, determined by the plant's genetics, may vary depending on environmental conditions, and the management of the pasture.

There was no interaction ( $p>0.05$ ) between cutting intensities and cutting heights for TPD, with an average of 28.06 tillers. A balance between the rates of appearance and the death of tillers was maintained due to the equal influence of the accumulation of rain, temperature, and solar radiation in all treatment groups throughout the rainy season (Caminha et al., 2010).

The FLL had no effect ( $p>0.05$ ) on the height of the cut and defoliation intensities. It can be observed that the cutting height influenced ( $\mathrm{p}<0.05)$ the SPS of A. gayanus (Table 3$)$.

The $90 \mathrm{~cm}$ pasture demonstrated a superior MDF to the pasture managed at 50 and $70 \mathrm{~cm}$, which had 427.7 and $357.2 \mathrm{~kg} \mathrm{ha}^{-1}$ of dry leaf weight, respectively. This can be explained by the greater number of leaves, LER, and LAR observed at this time, causing a greater increase in MDF. There was no difference $(p>0.05)$ in dry leaf mass attributable to the cutting intensities.

The highest dry mass of stalk was verified in the pasture managed with a cutting intensity of $50 \%$ (Table 3 ), which was associated with a higher residual height $(25,35$, and $45 \mathrm{~cm})$ at cutting heights of 50,70 and $90 \mathrm{~cm}$, respectively. Of the cutting heights, the largest mass of stalk was observed in pastures maintained at a height of $90 \mathrm{~cm}$. There was an increase in stalk of more than $100 \%$, while in leaves only $24.2 \%$, which is justified by the lower LB/C.

This effect can be justified based on the fact that grasses, when submitted to long periods of rest, have a high leaf area index, thus providing greater shading at the base of the canopy. Consequently, the stem elongates and exposes the newer leaves at the top of the pasture (Santos et al., 2018). This concurs with the highest SER at a height of $90 \mathrm{~cm}$ (Table 1).

The stalk is a considerably denser organ than the leaf blades (Medica et al., 2017), and its greater participation in the canopy may result in a greater forage mass, thus reflecting a greater DMTF, which was observed in the $90 \mathrm{~cm}$ pasture.

Table 2. Morphogenic and structural characteristics that did not show an interaction effect

\begin{tabular}{|c|c|c|c|c|c|}
\hline Height (cm) & $\begin{array}{c}\text { LER } \\
\left(\mathrm{cm} \mathrm{leaf}^{-1} \mathrm{~d}^{-1}\right)\end{array}$ & $\begin{array}{c}\text { LSR } \\
\left(\mathrm{cm} \mathrm{d}^{-1}\right)\end{array}$ & $\begin{array}{l}\mathrm{NL} \\
\text { (leat) }\end{array}$ & $\begin{array}{c}\text { TPD } \\
\text { (tillers) }\end{array}$ & $\begin{array}{c}\mathrm{FLL} \\
\left(\mathrm{cm} \mathrm{d}^{-1}\right)\end{array}$ \\
\hline 50 & $5.20 \mathrm{c}$ & $0.336 \mathrm{~b}$ & $1.49 b$ & $27.47 \mathrm{a}$ & $43.47 \mathrm{a}$ \\
\hline 70 & $6.05 b$ & $0.318 b$ & $1.69 \mathrm{ab}$ & $27.10 \mathrm{a}$ & $46.11 \mathrm{a}$ \\
\hline 90 & $6.89 \mathrm{a}$ & $0.957 \mathrm{a}$ & $1.87 \mathrm{a}$ & $29.61 \mathrm{a}$ & $47.18 \mathrm{a}$ \\
\hline \multicolumn{6}{|c|}{ Cutting intensity (\%) } \\
\hline 50 & $6.54 \mathrm{a}$ & $0.55 \mathrm{a}$ & $1.77 \mathrm{a}$ & $26.20 \mathrm{a}$ & $46.31 \mathrm{a}$ \\
\hline 70 & $5.55 \mathrm{~b}$ & $0.52 \mathrm{a}$ & $1.60 \mathrm{a}$ & $29.92 \mathrm{a}$ & $44.86 \mathrm{a}$ \\
\hline SEM & 0.2180 & 0.0721 & 0.0590 & 0.9710 & 1.1870 \\
\hline Height $^{1}$ & 0.0004 & $<0.0001$ & 0.0093 & 0.5353 & 0.4352 \\
\hline $\operatorname{lnt}^{2}$ & 0.0020 & 0.7211 & 0.0613 & 0.0716 & 0.5458 \\
\hline Height $x \operatorname{lnt}^{3}$ & 0.3631 & 0.8679 & 0.0613 & 0.9587 & 0.2371 \\
\hline
\end{tabular}

LER - Leaf elongation rate; LSR - Leaf senescence rate; NL - Number of leaves; TPD - Tiller population density; FLL- Final leaf length. Means followed by the same letter do not differ at $\mathrm{p} \leq 0.05$ by the Tukey test; 1 - Cutting height effect; 2 - Effect of cutting intensity; 3 - Effect of interaction; SEM - Standard error mean 
Table 3. Mean values of Andropogon spp. forage mass at different cutting heights and cutting intensities

\begin{tabular}{|c|c|c|c|c|c|c|}
\hline Height & DFM & DSM & MDF & DMTF & \multirow{2}{*}{ LB/SR } & \multirow{2}{*}{$\begin{array}{c}\text { TPD } \\
{\text { (tiller } m^{-2}}^{-2}\end{array}$} \\
\hline (cm) & \multicolumn{4}{|c|}{$\left(\mathrm{kg} \mathrm{ha}^{-1}\right)$} & & \\
\hline 50 & $1334.7 \mathrm{~b}$ & $725.4 \mathrm{~b}$ & $464.6 \mathrm{~b}$ & 2524.7 b & $1.94 \mathrm{a}$ & $544.13 \mathrm{a}$ \\
\hline 70 & $1405.2 b$ & 885.8 b & $486.5 \mathrm{~b}$ & $2777.6 \mathrm{~b}$ & $1.68 \mathrm{a}$ & $504.25 a$ \\
\hline 90 & $1762.4 \mathrm{a}$ & $1864.5 \mathrm{a}$ & $913.0 \mathrm{a}$ & $4540.0 \mathrm{a}$ & $1.07 \mathrm{~b}$ & $580.25 \mathrm{a}$ \\
\hline \multicolumn{7}{|c|}{ Cutting intensity (\%) } \\
\hline 50 & $1572.5 \mathrm{a}$ & $1377.6 \mathrm{a}$ & $846.22 \mathrm{a}$ & $3796.3 \mathrm{a}$ & $1.33 \mathrm{~b}$ & $509.50 \mathrm{a}$ \\
\hline 70 & $1429.1 \mathrm{a}$ & 939.6 b & $396.59 \mathrm{~b}$ & $2765.2 \mathrm{~b}$ & $1.80 \mathrm{a}$ & $576.25 \mathrm{a}$ \\
\hline SEM & 58.45 & 111.36 & 64.635 & 190.151 & 0.01 & 20.267 \\
\hline Height $^{1}$ & 0.0039 & $<0.0001$ & 0.0003 & $<0.0001$ & $<0.0001$ & 0.3018 \\
\hline $\operatorname{lnt}^{2}$ & 0.1796 & 0.0095 & $<0.0001$ & $<0.0001$ & 0.0031 & 0.098 \\
\hline Heightt $x \ln t^{3}$ & 0.4542 & 0.501 & 0.0541 & 0.2181 & 0.3900 & 0.361 \\
\hline
\end{tabular}

DFM - Dry forage mass; DSM - Dry stem mass; MDF - Mass of dead fodder; DMTF - Dry mass of total forage; LB/SR - Leaf blade/stem ratio; TPD - Tiller population density; Means followed by the same letter do not differ at $\mathrm{p} \leq 0.05$ by the Tukey test; 1 - Cutting height effect; 2 - Effect of cutting intensity; 3 - Effect of interaction; SEM - Standard error mean

When the pasture was managed at a cutting height of 90 $\mathrm{cm}$, a greater increase in MDF was observed of $49.11 \%$ and $46.71 \%$ in the 50 and $70 \mathrm{~cm}$ pastures, respectively, (Table 3). Higher levels of shade at the base of the grass canopy are inherent in pastures that are left taller, which results in a greater accumulation of dead material in the lower strata of the pasture (Santana et al., 2014). The cut intensity of 50\% showed a higher MDF than at $70 \%$. This is due to the higher residue height (25, 35 , and $45 \mathrm{~cm}$ ) at a cutting intensity of $50 \%$, which results in less incident light reaching the basal stratum of the pasture, thus promoting a greater accumulation of senescent material. In the pasture maintained at a height of $90 \mathrm{~cm}$, there was a higher production of DMTF. However, this higher DMTF is due to the greater stalk increase, as it is denser than the leaves, thus reducing the LB/SR. This response may be related to the large amount of leaves remaining in the plants maintained with greater residual height $(25,35$, and $45 \mathrm{~cm})$, since the recovery of the tiller community is favored.

According to Pimentel et al. (2016), after removal of the aerial part, the roots and stems act as sources of organic reserves, transferring carbohydrates and proteins to the leaf regrowth to restore the leaf area. At $70 \%$ cutting intensity, the residue was lower than $50 \%$, with values of 15,21 , and $27 \mathrm{~cm}$ for heights of 50,70, and $90 \mathrm{~cm}$, respectively. According to Sousa et al. (2010), Andropogon spp. have the highest apical meristem in managed pastures, and more severe cuts remove the apical meristem, decreasing the productive recovery of the pasture.

The blade/stem ratio (LB/SR) at heights of 50 and $70 \mathrm{~cm}$ was higher than at $90 \mathrm{~cm}$, due to the lower proportion of stems in the pastures managed at the lower heights (Table 3). According to Chaves et al. (2013), a higher blade stem ratio in the grass indicates a positive effect of defoliation intensity on the tillers, which occurred at the lower cutting heights.

For tiller population density (TPD), there was no interaction ( $p>0.05)$ between cutting heights and cutting intensities. Thus, it can be inferred that the management strategy promoted a dynamic balance between death, and the appearance of tillers.

TAR was not different between the cutting heights. At a cutting intensity of $70 \%$, a higher TAR of $64.50 \%$ was observed. The appearance of tillers is linked to the light regime, so it is assumed that $70 \%$ more light reaches the base of the canopy, which results in less competition for light, increasing the quality of light in the basal strata, thus promoting the development of buds in tillers (Santos \& Fonseca, 2016).
Table 4. Demographic patterns of Andropogon gayanus subjected to different cutting heights and cutting intensities

\begin{tabular}{|c|c|c|c|c|}
\hline $\begin{array}{c}\text { Cutting } \\
\text { Intensity } \\
\end{array}$ & TAR & TMort & TSR & \multirow[t]{2}{*}{ SIn } \\
\hline \multicolumn{4}{|c|}{ (\%) } & \\
\hline 50 & $41.35 \mathrm{~b}$ & $24.20 \mathrm{a}$ & $69.59 \mathrm{a}$ & $1.37 \mathrm{a}$ \\
\hline 70 & 64.50 a & $22.36 \mathrm{a}$ & $70.39 a$ & $1.63 \mathrm{a}$ \\
\hline SEM & 5.003 & 1.084 & 1.275 & 0.065 \\
\hline Height ${ }^{1}$ & 0.9219 & 0.6287 & 0.7482 & 0.7482 \\
\hline $\operatorname{lnt}^{2}$ & 0.0267 & 0.4283 & 0.1462 & 0.0661 \\
\hline Height $x \ln t^{3}$ & 0.6045 & 0.5222 & 0.2639 & 0.5016 \\
\hline
\end{tabular}

TAR - Tiller appearance rate; TMort - Tiller mortality rate; TSR - Tiller survival rate; SIn - Stability index; Means followed by the same letter do not differ at $\mathrm{p} \leq 0.05$ by the Tukey test; 1 - Cutting height effect; 2 - Effect of cutting intensity; 3 - Interaction effect; SEM - Standard error mean

The tiller is the basic unit of the grass, and the structural characteristics of the tillers determine the structure of the pasture. The largest number of live tillers is essential for the productivity of the pasture, as long as there is no compromise in its growth (Santos et al., 2017). A greater density of tillers ensures denser pastures, which sustains more livestock units (Fonseca et al., 2013).

Tiller mortality did not differ between the management strategies, because of phenotypic plasticity of the growth and development in tropical grasses. According to Lemaire and Chapman (1996), gradual and reversible modifications of plant morphology in a defoliated environment are characterized by phenotypic or morphological plasticity of the forage plant. In this way, the tillers may show compensatory responses to maintain a perennial population of tillers in the pasture under different management strategies employed by humans (Hodgson \& Silva, 2002).

Regarding the tiller stability index, no effect of cutting height or intensity were observed ( $p>0.05)$. Values of the population stability index greater than 1.0 indicate that the survival, together with the appearance of new tillers, of the population is stable, resulting from dynamic balance (Bahmani et al., 2003). Stability of tillering of A. gayanus was evident in the different management strategies.

\section{Conclusion}

A gayanus grass pasture has better structural, morphogenic, demographic, and productive characteristics when handled with intermittent defoliation, at a cutting height of $70 \mathrm{~cm}$ and cutting intensity of $90 \%$. 


\section{Literature Cited}

Araújo, D. L. da C.; Oliveira, M. E. de; Lopes, J. B.; Alves, A. de A.; Rodrigues, M. M.; Moura, R. L. de; Santos, M. S. dos. Características morfogênicas, estruturais e padrões demográficos de perfilhos em pastagem de capim-andropógon sob diferentes ofertas de forragem. Semina: Ciências Agrárias, v.36, p.3303-3314, 2015. https://doi.org/10.5433/1679-0359.2015v36n5p3303

Bahmani, I.; Thom, E. R.; Matthew, C.; Hooper, R.J.; Lemaire,G. Tiller dynamics of perennial ryegrass cultivars derived from different New Zealand ecotypes: effects of cultivars, season, nitrogen fertilizer, and irrigation. Australian Journal of Agricultural Research, v.54, p.803-817, 2003. https://doi.org/10.1071/AR02135

Caminha, F. O.; Silva, S. C. da; Paiva A. J.; Pereira L. E. T.; Mesquita, P. de; Guarda, V. D. Estabilidade da população de perfilhos de capim- marandu sob lotação contínua e adubação nitrogenada. Pesquisa Agropecuária Brasileira, v.45, p.213-220, 2010. https:// doi.org/10.1590/S0100-204X2010000200013

Carvalho, C. A. B. de; Silva, C. da; Sbrissia, A. F.; Pinto, L. F. de M.; Carnevalli, R. A.; Fagundes, J. L.; Pedreira, C. G. S. Demografia do perfilhamento e taxas de acúmulo de matéria seca em capim 'Tifton 85' sob pastejo. Scientia Agricola, v.57, p.591-600, 2000. https://doi.org/10.1590/S0103-90162000000400001

Chaves, C. S.; Gomide, C. A. de M.; Ribeiro, K. G.; Paciullo, D. S. C.; Ledo, F. J. da S.; Costa, I. de A.; Campana, L. L. Forage production of elephant grass under intermittent stocking. Pesquisa Agropecuária Brasileira, v.48, p.234-240, 2013. https:// doi.org/10.1590/S0100-204X2013000200015

Fonseca, L.; Carvalho, P. C. F.; Mezzalira, J. C.; Bremm, C.; Galli, J.; Gregorini, P. Effect of sward surface height and level of herbage depletion on bite features of cattle grazing Sorghum bicolor swards. Journal of Animal Science, v.9, p.1-9, 2013. https://doi. org/10.2527/jas.2012-5602

Hodgson, J.; Silva, S. C. da. Options in tropical pasture management. In: Reunião Anual da Sociedade Brasileira de Zootecnia, 39. Simpósio Internacional de Forragicultura. Anais... Recife, p.180202, 2002.

Lemaire, G.; Chapman, D. Tissue flows in grazed plant communties. In: Hodgson, J.; Illius, A. W. (eds.). The ecology and management of grazing system. Wallingford: CAB international, p. 3-36, 1996.

Lemaire, G.; Inra, F.; Hodgson, J. Grassland productivity and ecosystem services. Wallingford: CABI, 2011. 312p. https://doi. org/10.1079/9781845938093.0000

Martuscello, J. A.; Silva, L. P. da; Cunha, D. N. F. V. da; Batista, A. C. dos S.; Braz, T. G. dos S.; Ferreira, P. S. Adubação nitrogenada em capim-Massai: Morfogênese e produção. Ciência Animal Brasileira, v.16, p.1-13, 2015. https://doi.org/10.1590/108968916 i118730

Medica, J. A. de S.; Santos, M. E. R.; Reis, N. S.; Silva, N. A. M. da; Ferreira Neto, J. G. Índice de horizontalidade e remoção de tecidos do capim-marandú. Ciência Animal Brasileira, v.18, p.1-15, 2017. https://doi.org/10.1590/1089-6891v18e-43267
Pimentel, L. R. M.; Bayão, G. F.V.; Lelis, D. L.; Cardoso, A. J. da S.; Saldarriaga, F. V.; Melo, C. C. V.; Souza, F. B. M. de; Pimentel, A. C. de S.; Fonseca, D. M. da; Santos, M. E. R. Ecofisiologia de plantas forrageiras. Pubvet, v.10, p.666-679, 2016. https://doi. org/10.22256/pubvet.v10n9.666-679

Santana, S. S. Fonseca. D. M. da; Santos, M. E. R.; Sousa, B. M. de L.; Gomes, V. M.; Nascimento Júnior, D. do Initial height of pasture deferred and utilize in winter and tillering dnamics of signal grass during the following spring. Acta Scientiarum. Animal Sciences. v.36. p.17-23, 2014. https://doi.org/10.4025/actascianimsci. v36i1.20463

Santos, E. M. R.; Carvalho, B. H. R.; Rodrigues, P. H. M.; Basso, K. C.; Carvalho, A. N. de. Características estruturais do capim-marandu diferido com alturas e doses de nitrogênio variáveis. Archivos de Zootecnia, v.67, p.420-426. 2018. https://doi.org/10.21071/ az.v67i259.3800

Santos, M. E. R.; Fonseca, D. M. da. Adubação de pastagens em sistemas de produção animal. Viçosa (MG): Editora UFV, 311p, 2016.

Santos, M. E. R.; Fonseca, D. M. da; Santos, T. G. do B.; Silva, S. P.; Gomes, V. M.; Silva, G. P. Morphogenic and structural characteristics of tillers on areas with signalgrass pasture varying on height. Revista Brasileira de Zootecnia, v. 40, p.535-542, 2011. https://doi.org/10.1590/S1516-35982011000300010

Santos, M. E. R.; Sousa, B. M. de L.; Rocha, G. de O.; Freitas, C. A. S.; Silveira, M. C. T. da; Sousa, D. O. C. de. Estrutura do dossel e características de perfilhos em pastos de capim-piatã manejados com doses de nitrogênio e períodos de diferimento variáveis. Ciência Animal Brasileira, v.18, p.1-13, 2017. https:// doi.org/10.1590/1089-6891v18e-37547

SAS - Stastistical Analysis System. User's guide statistics. 9.ed. Cary: SAS Institute, 2002. 943p

Sbrissia, A. F.; Silva, S. C. da; Sarmento, D. O. L.; Molan, L. K.; Andrade, F. M. E.; Gonçalves, A. C.; Lupinacci, A.V. Tillering dynamics in palisadegrass swards continuously stocked by cattle. Plant Ecology, v.206, p.349-359, 2010. https://doi.org/10.1007/ s11258-009-9647-7

Silva, S. C. da; Sbrissia, A. F. A planta forrageira no sistema de produção. In: Simpósio sobre Manejo da Pastagem, 17. 2001, Piracicaba. Anais... Piracicaba: Fealq, 2001. p.71-88.

Sousa, B. M. de L.; Nascimento Júnior, D. do; Silva, S. C. da; Monteiro, H. C. de F.; Rodrigues, C. S.; Fonseca, D. M. da; Silveira, M. C. T. da; Sbrissia, A. F. Morphogenetic and structural characteristics of Andropogon grass submitted to different cutting heights. Revista Brasileira de Zootecnia, v.39, p.2141-2147, 2010. https:// doi.org/10.1590/S1516-35982010001000006

Veras, V. S.; Oliveira, M. E.; Lacerda, M. S. B.; Carvalho, T. B.; Alves, A. A. Produção de biomassa e estrutura do pasto de capimandropogon em sistema silvipastoril e monocultura. Arquivos Brasileiros de Medicina Veterinária e Zootecnia, v.62, p.200-207, 2010. https://doi.org/10.1590/S0102-09352010000100027 